\title{
What affects bank debt rejections? Bank lending conditions for UK SMEs
}

\author{
Mingchen Sun, Claudia Girardone, Raffaella Calabrese
}

\begin{abstract}
$\underline{\text { Abstract }}$
Using the UK SMEs Finance Monitor data over 2011-2017, we explore the determinants of bank debt rejections for UK SMEs. In the wake of the global financial crisis, business overdrafts and term loans show slightly different trends although the factors affecting rejections are similar. We find that since 2014 rejection rates reduced for both facilities and they remained stable in the run-up to the Brexit referendum and its immediate aftermath, although export and import SMEs operating in industries with a high share of EU trade experienced tighter conditions. Further, we present robust evidence that firms with female owners, organised in partnerships, and with a higher initial credit balance are more likely to have their credit application approved. Finally, younger, smaller and more innovative SMEs are more likely to be rejected, while their chance of being successful in their credit applications increases substantially after 2014 .
\end{abstract}

Keywords: Small and Medium-Sized Enterprises; Access to Finance; Overdrafts; Term Loans.

JEL classification: D22; G28; G32. 


\section{Introduction}

Small and medium-sized enterprises (SMEs) play a key role in virtually every nation primarily because they are drivers to job creation and local economic growth. In the UK, they constitute $99.3 \%$ of all private sector enterprises, and over the period 2011-17 alone, their number increased by about $24 \%$ to 5.7 million. They also contribute approximately $60 \%$ of all private sector employment and $51 \%$ of all private sector annual turnovers (DBEIS, 2017). SMEs rely heavily on bank debt as external financing sources and are more likely to face credit constraints relative to large firms. This is because SMEs have limited net wealth and are often less informationally transparent than large firms; they have also lower formal reporting needs and less external monitoring (Berger et al., 2005; Armstrong et al., 2013; Udell, 2015).

Over the past decade the UK government launched several schemes to facilitate formal bank lending for SMEs, such as the Funding for Lending scheme in 2012. Another way to assist small businesses in finding bank credit was to create the British Business Bank in 2014. However, the slow economic recovery in the aftermath of the global financial crisis and June 2016's referendum results on Brexit, triggered a sense of risk and instability for businesses of all size and sectors, including banks and financial firms. Among the key concerns were the prospect of leaving the European single market and the uncertainty surrounding the regulatory environment as the UK will have to convert and adapt EU legislation (Filippaios and Stone, 2017). In this paper we investigate the following three main research questions: do bank debt conditions for SMEs change in the run up and immediately after the Brexit referendum in 2016? What firm- specific characteristics in terms, for example, of size, age and 
type of activities, may be most impacted by changes in the credit market? What are the key drivers of bank debt rejections?.

This study offers significant contributions to the literature by providing an up-to-date evaluation of bank credit conditions and unique insights into the problem of debt rejections for UK SMEs. First, previous studies on UK lending conditions mostly focus on the period before and after the global financial crisis up to 2013 (e.g. Fraser, 2012; Armstrong et al., 2013; Cowling et al., 2016). This paper is among only few studies (Brown et al., 2019; Calabrese et al., 2020) available in the literature that considers the period of 'great uncertainty' around the Brexit referendum in 2016. We pay particular attention to international traded SMEs that might be heavily influenced by the outcome of the vote.

Second, based on our knowledge, this is the first paper that explores the specific lending conditions for firm size and company's age. Start-ups are often very small, nonetheless they give a strong contribution to net employment growth; this was true even during the crisis, as evidenced, for example, in the cross-country study by Criscuolo et al. (2014). Previous studies show that smaller and younger SMEs are found to have difficulties in accessing bank credit (e.g. Coleman, 2004; Cowling et al., 2012) but they do not show the determinants of credit application for each SME's sub-group.

Our last contribution relates to the literature on the determinants of debt rejections. Several firm and owner features are identified as important determinants (e.g. Fraser, 2009; Cole and Dietrich, 2013; Zhao and Jones-Evans, 2017). However, the role of credit balance is generally ignored, although it is found to help banks alleviate moral hazard problems (Mester et al., 2006). One plausible reason is the sensitivity of this information that makes firms reluctant to disclose, leading to a large number of missing values in the data set and give the first attempt to test the effect of credit balance on bank debt 
rejections. To the best of our knowledge, we provide the first attempt to test the effect of credit balance on bank debt rejections.

Our data are drawn from a rich firm-level survey data drawn from the UK SMEs Finance Monitor. The breadth of the survey allows us to consider many important aspects in the analysis including ownership (for example male/female), manager characteristics, bank relationships, firm demographics (size and age) and products (including credit balance). We obtain that over the long time frame for this analysis (2010-2017), the rejection rates for SMEs dropped but that was held back by the uncertainty surrounding the Brexit referendum. We distinguish between two types of bank credit, namely business overdrafts facilities and term loans, as firms typically use them for different purposes. Business overdrafts are ideal for firms with fluctuating financing needs, so they are used to ease pressures on working capital and as a back-up for unanticipated expenditures; while term loans are typically used for longer term purposes and generally firm expansion. Overdraft applicants typically have different characteristics compared to loan applicants and the relevant literature has previously indicated that the determinants of overdraft rejections can differ significantly from those of loans' (Armstrong et al., 2013; Lee and Brown, 2017; Zhao and Jones-Evans, 2017).

Our main findings indicate that relative to the years in the aftermath of the global financial crisis (2010-11), the overdraft and loan markets appear to follow slightly different patterns. We present robust evidence that rejection rates initially dropped after 2014. They remained stable in the run-up to the Brexit referendum and its immediate aftermath, although export and firms operating in industries with a high share of EU trade experienced tighter conditions. We find that SMEs with female owners and organised in partnerships, and with a higher initial credit balance are more likely to be approved. 
While younger, smaller and more innovative SMEs with lower application amounts are more likely to be rejected both in the case of loans and overdrafts. An in-depth analysis on firm size and age shows that relative to 2013, micro firms (less than 10 employees and turnover $<£ 2 m$ ) face lower rejection rates in the following four years, while other SMEs do not. Further, our results confirm that start-ups ( $<2$ years) experience significantly improved conditions in recent years, particularly in the case of overdrafts.

The rest of this paper is organised as follows. Section 2 provides a brief review of relevant theoretical and empirical studies and sets out the key research hypotheses. Sections 3 describes the data. Section 4 explains the model and the variables employed in the regressions. The empirical results and robustness tests are presented and discussed in Sections 5 and 6, respectively. Finally, Section 7 concludes and provides a discussion of the main related policy issues.

\section{Selected literature review and main hypotheses}

\subsection{Theoretical literature}

The seminal theoretical studies of Jaffee and Russell (1976) and Stiglitz and Weiss (1981) develop a framework related to the rationale of credit rationing that occurs when banks restrict their lending even if 'good' borrowers are willing to pay higher interest rates. This is because the rise in interest rate increases the risk of the pool of potential borrowers but banks are unable to distinguish good borrowers from bad borrowers due to the imperfect information in credit markets (adverse selection). In order to pay off the higher interests, borrowers might change their behaviour and choose a riskier project (moral hazard). Such reasons lead banks to ration credit, especially when the information asymmetry problem 
is severe. In this sense, small businesses, more informationally opaque, are more likely to be credit rationed relative to large firms. Specifically, two types of credit rationing came into being when borrowers receive a smaller amount than they request (type 1) or nothing (type 2) (Drakos and Giannakopoulos, 2011).

To overcome adverse selection and moral hazard problems, banks have developed several lending technologies (Boot, 2000; Berger and Udell, 2002, 2006), such as relationship lending relying on "soft" information (qualitative information obtained over time via contacts with firms, owners and the local community) and transaction lending relying on "hard" information (quantitative information, such as data derived from balance sheets and/or collateral guarantees). In practice, lending technologies are applied synergistically when banks make decisions on debt applications (Udell, 2015). Therefore, any information utilised in lending technologies, no matter if soft or hard, can mitigate credit rationing and those acting as signals of high credit risk, i.e. lower ability to pay off the debt will increase the probability of debt rejection.

\subsection{UK bank lending conditions}

Inspired by the theoretical models just presented, a relatively large body of empirical research ensued that focuses on the analysis of credit rationing for SMEs (e.g. Berger and Udell, 1992; Freel, 2007). Most empirical studies employ survey data to identify credit rationed small businesses (e.g. Drakos and Giannakopoulos, 2011; Cenni et al., 2015). Early studies only include in their data samples credit rationed firms (type 1, type 2 or both) and successful applicants (e.g. Bodt et al., 2005; Freel, 2007). This potentially leads to sample bias as the applications are not random. To solve this problem, 
recent studies (e.g. Cenni et al., 2015; Cowling et al., 2016) employ advanced techniques, such as Heckman models to incorporate factors affecting demand and supply of bank credit in one structure system.

One approach to assess bank lending conditions is to analyse the trend shown by the firms' total amount of outstanding debt. However, this is not informative enough as it is difficult to disentangle the supply-side changes (i.e. banks loosening lending standards) from the demand-side changes (e.g. firms become more or less credit risky). A better approach to assess lending conditions is using time dummies to proxy the market changes of bank debt rejections over time after controlling for sufficient risk characteristics from the demand side (e.g. Fraser, 2012; Armstrong et al., 2013). For the UK market, lack of sufficient relevant data mean that there are only a few papers empirically examining how the credit market conditions vary over recent years.

The existing body of literature looks into UK bank lending conditions for SMEs up to 2013, typically focusing on a relatively short time span. In this study we employ a longer time frame for the analysis (2010-2017). We expect that rejection rates would first decrease at the beginning of the period under investigation then increase in the run-up to the Brexit referendum in 2016 given to widespread uncertainty with investors and firms suffering from unknown trading and/or regulatory environment as the UK decided to leave the European Union. Therefore our first hypothesis (H1) can be formulated as follows:

H1: Rejection rates diminished post financial crisis but increased in the run-up to the Brexit referendum and its immediate aftermath. 
Not all companies suffered from worse credit conditions during and after the Brexit referendum. The uncertainty generated by Brexit resulted in a dramatic drop in the pound sterling's value, increasing the costs of import activities and decreasing the profits of SMEs activities. The negative impact of Brexit was somewhat proved by the evidence that export and import SMEs were inclined to regard Brexit as an obstacle to business success (Brown et al., 2019). Given that UK export SMEs had typically greater difficulties in accessing bank credit (Cowling et al., 2016), in such context, banks will be even more cautious in lending to export or import SMEs. In addition, in light of the changes in the trading outlook in the EU, banks might ration credit more to export or import firms which operate in industries with a high share of EU trade. Therefore, we hypothesise that:

H2: Export/Import-oriented UK SMEs, especially those in industries with a high share of EU trade, suffered from tighter credit conditions during and after the Brexit referendum.

Extending the finding by Armstrong et al. (2013) that uncertainty has a stronger impact on bank lending for SMEs than large firms, we speculate that the impact of the uncertainty brought by Brexit might also differ by firm size within SMEs. Given that firm size and age play important roles in SME's access to bank credit (e.g. Coleman, 2004; Cowling et al., 2012), we formulate our third hypothesis:

H3: The changes in bank lending conditions in UK SMEs differ by firm size and age. 


\subsection{The determinants of bank debt rejections}

In theory, factors which can reduce the information asymmetry between SMEs and banks, no matter if related to soft or hard information, can affect bank debt rejections. Empirical studies tend to identify selected owner/manager features, factors associated to relationship banking as well as firm characteristics as determinants (e.g. Cole, 1998; Fraser, 2009; Cole and Dietrich, 2013).

The gender of the owner/manager can influence bank debt rejections in the sense that femaleowned/led SMEs tend to be smaller, younger, less profitable (Fasci and Valdez, 1998), slower-growing (Cooper et al., 1994) and less likely to survive (Fairlie and Robb, 2009), suggesting they are potentially riskier and thus more likely to have difficulties in getting funded. Early studies (e.g. Riding and Swift, 1990; Coleman, 2000) provide evidence to this argument; whereas recently, for example, Cowling et al. (2016) find female-owned/led SMEs in the UK are less likely to be rejected. In addition, owners' age (Zhao and Jones-Evans, 2017) and financial qualifications (Cowling et al., 2016) are usually found to be positively associated with bank credit availability for UK SMEs.

In relationship lending, banks are able to gather soft information about their customers through repeated interactions (Boot, 2000). Over time, the collection of the information on firms' creditworthiness builds up and if a bank supplies a bundle rather than a single product to a firm, it is much easier and less costly for monitoring (Fraser, 2009). The lower information asymmetry resulted from a longer-term and more concentrated bank relationship is found to help SMEs get better access to bank credit (e.g. Petersen and Rajan, 1994; Berger and Udell, 1995; Kysucky and Norden, 2015). However, Fraser (2009) find that for UK SMEs, not only the length, but also the concentration of the bank relationship is insignificant. The information obtained from the applicants' previous suppliers 
are sufficient for banks to make decisions so that they do not need to establish extra close relationships with SMEs.

As for firm characteristics, it is harder for younger and smaller SMEs to access bank credit (e.g. Coleman, 2004; Cowling et al., 2012). This could be because older and larger firms are more likely to have a track record of business financial information and credit history that reduce the information asymmetry (Fraser et al., 2015). They are also more able to provide sufficient collateral (Armstrong et al., 2013) and payoff the debt (Drakos and Giannakopoulos, 2011). Industry sector is another factor that may affect SMEs' access to finance. The rationale is that firms in the same industry are subject to similar market conditions (Freel et al., 2012) and therefore, belonging to a certain industry classification can act as a signal for business risk. The importance of high-growth and geographical disparities is highlighted by Moro et al. (2017) and Zhao and Jones-Evans (2017) respectively while innovative SMEs appear to have more difficulties accessing finance (Freel, 2007; Lee at al., 2015).

However, many important variables, such as the presence of a credit balance, have not been examined before, mainly due to missing data problems. Credit balance refers to the amount that a firm usually holds in its current and deposit accounts. By virtue of the information in credit balance, banks can assess borrower's ability to generate profits and predict its probability of default, which is valuable in the UK where small businesses are exempted to get an audit of their annual accounts. Banks can also monitor the changes in the credit balance to get rid of moral hazard problems, especially when the SME has an exclusive relationship with the bank (Mester et al., 2006). Besides, credit balance makes it easier for banks to discover borrowers' losses. This can motive SMEs to take actions to generate higher return (Nakamura, 1991). Therefore, banks can use it as a 'selection' tool during 
applications, a 'monitoring' tool after applications and also a 'buffer' in the event of default. The higher the credit balance, the lower the probability of default, the stronger the 'buffer' and the less likely their applications get rejected.

H4: SMEs with higher credit balance are less likely to be rejected when they apply for bank financing.

\section{Data}

The dataset used in this study is drawn from the Small and Medium-Sized Enterprise Finance Monitor (SMEFM) accessed from the UK Data Archive (BDRC Continental, 2018), which provides micro firm-level survey data collected from 2011 Q1Q2 to 2017 Q4. ${ }^{1}$ Since the survey asks for SMEs' experiences in previous 12 months, we have information on UK SMEs from 2010 to 2017. However applications in the first and last year under study (2010 and in 2017) are underestimated because they refer to the previous period. SMEs are defined as firms with no more than 250 employees and no more than $£ 25$ million annual turnovers, slightly lower than the limit set by European Commission. ${ }^{2}$ They should also have the following characteristics to qualify for the interviews: (1) not $50 \%+$ owned by another company (2) not run as a social enterprise or as a not for profit organization. Around 5,000 different SMEs were interviewed in each wave (27 in total, corresponding to 131,332 observations).

\footnotetext{
${ }^{1}$ The first wave survey was performed in February-May 2011 and is specially denoted by "2011 Q1Q2". Subsequent surveys were undertaken in standard quarter periods (January-March, April-June, July-September and October-December). ${ }^{2}$ In actual facts, there is no single SMEs definition within the UK government and different thresholds are defined depending on the purposes, for example, accounting and tax relief etc.. The EU definition that came into force on 1 January 2005 uses these thresholds: micro firms (0-9 employees and an annual turnover of not more than $€ 2 \mathrm{~m}$ or a balance sheet no greater than $€ 2 \mathrm{~m}$ ); small (10-49 employees and an annual turnover of not more than $€ 10 \mathrm{~m}$ or a balance sheet no greater than $€ 10 \mathrm{~m}$ ); and medium (50-249 employees and an annual turnover of not more than $€ 50 \mathrm{~m}$ or a balance sheet no greater than $€ 43 \mathrm{~m})$.
} 
The database asks for their experiences of seeking and obtaining external finance in the previous 12 months, future finance needs and barriers for future growth, as well as the characteristics of the SMEs and their owners/managers. Therefore, the survey data are in repeated-measured structure, instead of panel structure.

Unlike in most European countries, UK SMEs demand more credit lines than loans as finance sources (DBIS, 2016). Therefore, we construct and analyse two separate datasets: one for business overdraft and the other for term loan applications. We delete observations with no initial outcome of their applications and those that refer to the year $2009 .{ }^{3}$ Our final sample includes a total of 16,537 observations, split into two separate samples: 10,673 observations for overdraft and 5,864 for loans.

Table A1 in the Appendix reports the sample size in each survey wave.

<Insert Table 1 around here>

Credit lines are typically shorter term and lower in volume than loans. Table 1 illustrates different reasons for overdraft (Panel A) and loan (Panel B) applications. Most SMEs use overdrafts as working capital to help with day to day cash flow management (81\%), as a safety net just in case (39\%) or to cover short term gaps until funds are available (26\%). On the other hand, $31 \%$ of SMEs apply for loans to expand their businesses (29\% domestically and $2 \%$ overseas), purchase premises (27\%) and equipment $(26 \%)$.

\footnotetext{
${ }^{3}$ Since the survey asks for SMEs' experiences in previous 12 months, the first wave survey conducted in 2011 should collect information in 2010. Therefore, applications in 2009 (the information before 2010) are regarded as outliers and removed from the sample.
} 


\section{<Insert Table 2 around here>}

Table 2 displays the number of SMEs which have applied for bank financing by year over the studied period. ${ }^{4}$ Overdraft applicants are almost twice as many the number of loan applicants in all years. We saw before that high needs for working capital and day-to-day liquidity are driving overdraft applications. Excluding 2010, Table 2 also reveals a dramatic drop (by nearly 2/3) in number of applications for both overdrafts and loans. Although the number of applications cannot measure bank credit demand accurately due to a likely "discouragement factor" at play (i.e. when SMEs who have positive financing needs do not make an application for fear of rejection), the trend described above is suggestive of a decreasing bank credit demand in the wake of the financial crisis. A report by DBIS (2015) highlights that - excluding SMEs with no employees -, fewer UK SMEs sought finance in $2014(19 \%)$, relative to $2012(24 \%)$ and $2010(26 \%)$. A possible reason is that firms adjust their business plans to slow down their growth during a crisis. This allows firms to accumulate enough internal funds and therefore do not demand external bank debt after the recession (BBB, 2016). Political and economic uncertainty around Brexit have likely affected firms' investment plans in the most recent years (Brown et al., 2019).

\footnotetext{
4 The data for applications in 2010 and 2017 are incomplete because less surveys covered these two periods, compared to other years, due to the way the survey is formulated (see also footnote 2). Specifically, the survey asked SMEs' experience over the past 12 months, which means applications in 2013 were surveyed from wave 8 (Q1 2013) to wave 15 (Q4 2014). However, applications in 2010 were only surveyed in the first 3 waves (only 3 waves were conducted in 2011) and applications in 2017 were only surveyed in the last 4 waves.
} 
The rejection rate is defined as "the proportion of firms which applied for credit and were either refused outright or received less credit than they requested, as a proportion of firms applying" (Armstrong et al., 2013, p. R41). The last two columns in Table 2 illustrate that the bank debt rejection rates during 2010-2017 is higher for loans than overdrafts in every year, reflecting the preference of banks to issuing low volume, contingent short-term finance (see also DBIS, 2016). This could also partially explain the lower number of loan applications in Table 2 since, as mentioned earlier, higher rejection rates could subsequently increase discouragement and thus reduce the number of applications. Table 2 also shows that for both overdrafts and loans, the rejection rates appear considerably higher in 2010-2013 compared to more recent years. This trend implies a tight credit condition during the great recession until 2013 and seems to hint to a greater banks' propensity to lend in more recent years, both in terms of overdrafts and loans. However it is possible to note that conditions are slightly tight again, particularly for loans in 2016, the year of the Brexit referendum.

\section{Model and variables description}

Here we construct the econometric models to test our hypotheses. The outcome of the application from the $i$-th SME (for $i=1,2, \ldots$, n) can be described by a Bernoulli random variable $Y_{i}$, so that:

$$
Y_{i}=\left\{\begin{array}{l}
1 \quad \text { if the } i-\text { th } S M E \text { is rejected } \\
0 \quad \text { if the } i-\text { th } S M E \text { is not rejected }
\end{array}\right.
$$

where a firm is defined as being rejected if it is either refused outright or receives less credit than it requests. By definition, bank debt rejection can only be observed if the firm actually applies for bank 
finance. Since the application decisions are not random, there might be sample selection bias if firms

which do not apply are omitted from the analysis. Following previous studies (e.g. Cenni et al., 2015;

Cowling et al., 2016), we employ the probit model with sample selection ${ }^{5}$ (Van de Ven and Van Pragg

1981) to model the demand and supply of bank credit, but find no selection bias in our overdraft and

loan sample. Therefore, a single regression model on bank debt rejection is appropriate. Considering

that interpretations are easier in logistic models than probit models, finally we decide to employ

logistic models for the empirical investigation. Specifically, let $\pi_{i}$ represent the probability of bank

debt rejection of $i$-th SME, thus $\pi_{i}=\operatorname{Pr}\left(Y_{i}=1\right)$. To estimate $\pi_{i}$, consider a covariate vector $X_{i}$

and a link function $g($.$) which is monotonic and twice differentiable such that:$

$$
g\left(\pi_{i}\right)=X_{i}^{T} \beta
$$

where $\beta$ denotes the unknown parameters vector to be estimated. The link function is the logit link

based on the symmetric logistic distribution that can be described as follows:

$$
\ln \left(\frac{\pi_{i}}{1-\pi_{i}}\right)=X_{i}^{T} \beta
$$

\footnotetext{
5 The results are not reported for brevity, but available upon request from the authors. This model is an extended Heckman model using maximum likelihood estimation. The dependent variable in the selection equation is whether a firm applies for bank debt and the dependent variable in the outcome equation is whether the application is rejected. The variable 'management account' and 'use of credit card' (see definitions in Table 3), are used as the selection criterion for both the overdraft and the loan sample as these two variables have been found significant in the selection equation (that is, related to the application decision making) but insignificant in the outcome equation (that is, unrelated to the bank decision making). The correlation coefficient between the two equations is insignificant for both overdrafts $(0.1781$ with p-value 0.11 ) and loans (0.1871 with p-value 0.34$)$, indicating there is no selection bias in our samples.
} 
In order to avoid the potential biased and/or inefficient estimated coefficients resulted from deletion of incomplete observations (White et al., 2011) ${ }^{6}$, we apply multiple imputations (MI) to deal with the missing values in our survey data (Allison, 2012). We adopt fully conditional specification (FCS) implemented by chained equations algorithm because it is a non-parametric approach that is based on three main steps: imputation, analysis and pooling. ${ }^{7}$ In the first step, plausible values are utilised to fill in the missing values by using other independent variables as predictors and iterating over the conditional densities. Several complete datasets can be generated in this step. Then, completedata methods are applied in each separate complete dataset. Finally, Rubin's rules are used to combine the results obtained in the second step. The rule incorporates "both within-imputation variability (uncertainty about the results from one imputed data set) and between-imputation variability (reflecting the uncertainty due to the missing information)" (White et al., 2011, p. 378).

How many complete datasets should be generated, which is also referred as the number of imputations, has been widely discussed (e.g. Schafer, 1999; Graham et al., 2007). In this paper, we follow White et al. (2011)'s recommendation which is more flexible: the number of imputations should be similar to the percentage of cases that are incomplete. Approximately $35 \%$ observations for overdrafts (40\% for loans) have missing values. Therefore, 35 imputed datasets are generated for overdrafts (40 for loans). The percentages of missing values in the corresponding variables are reported in the note to Table 4. The independent variable of interest (application date) has $7 \%$ missing values

${ }^{6}$ Complete-case analysis is appropriate only if the data are missing completely at random (MCAR). We run the Little's MCAR test. The chi-square statistic is 3643 for overdraft sample and 3112 for loan sample, which are highly significant. Therefore, the missing data in our sample are not MCAR patterns and complete-case analysis will be inappropriate in such a context.

7 This is implemented in the programming language R using the package "mice" (Buuren and Groothuis-Oudshoorn, 2011). 
for overdrafts and $12 \%$ missing values for loans. Credit balance has the highest percentages of missing values (19\% for overdrafts and $20 \%$ for loans). ${ }^{8}$

To control for sufficient risk characteristics, we incorporate a number of explanatory variables in our regressions (see Table 3). However, some of them may contain no or replicate information on bank debt rejection. Adding noninformative variables can bring noise and impair model performance (Ritter, 2014), To tackle this issue, we follow Wood et al. (2008) and use a backward stepwise selection approach. At first, the model with all the potential covariates is estimated. Then, the explanatory variable with the lowest significance level is dropped and the Wald test is used to test whether the dropped covariates (except the most recently dropped) should be re-introduced into the model. ${ }^{9}$ If the dropped variables are not re-included in the model, the model is re-estimated excluding the dropped covariates. This iterative procedure is applied until all the covariates in the model are significant at least $10 \%$ significance level. Therefore, the results reported in the next section only include significant explanatory variables.

Table 3 provides the definitions of all variables used in equation (3). ${ }^{10}$ The dependent variable is the bank debt rejection, a binary variable equal to 1 if the firm was refused outright or received less credit than it requested, and zero otherwise.

<Insert Table 3 around here>

\footnotetext{
8 This is likely the reason why, its effects has not been examined before in previous studies (e.g. Lee and Brown, 2017; Rostamkalaei and Freel, 2017) that use the same data set.

9 We use the function 'pool.compare' available in the R package 'mice' to implement the Wald test.

${ }_{10}$ Compared to the variable list in Table 3, some variables are absent in Table 5. This is because these variables are insignificant and thus removed from the regression model after we apply the backward stepwise selection technique. It does not mean that we do not include these variables when we run regressions. Besides, the empty rows for application date in Table 5-8 also mean the dummy variables are insignificant and removed from the model.
} 
One important variable is the application date for which we include eight dummy variables, (one for each year) to proxy for changes in credit market conditions as in Fraser (2012) and Armstrong et al. (2013). A higher rejection rate is expected for applications in 2016 the year of the Brexit referendum. We also include credit balance to test Hypothesis 4, and incorporate eight dummies, expecting significant higher marginal effects for higher credit balance dummies.

Following the main literature on the determinants of access to bank finance for SMEs (e.g. Cowling et al., 2016; Lee and Brown, 2017) the additional independent variables included in the model can be mainly divided into four groups: owner/manager characteristics, bank relationship and/or products, firm characteristics ${ }^{11}$, and application process-related variables. The related descriptive statistics can be found in Table 4. A 'typical' applicant for both overdrafts and loans (first and sixth columns) holds less than $£ 5,000$ in its current and deposit account, which is owned/led solely by a male owner aged more than 50 years without sufficient financial knowledge. It only approaches one bank (the main bank) and does not use a credit card. With less than 10 employees and $£ 1 \mathrm{~m}-£ 4.9 \mathrm{~m}$ annual turnover to generate profits, the typical applicant is established for more than 15 years, located in the South East and operating in the Construction industry. It produces business plans and regular financial statements, has a low risk level but does not have international (import /export) and innovative activities. It typically uses business accounts to apply for credit in the range $£ 10,000-49,000$

\footnotetext{
11 For further analysis to test our third hypothesis (H3), we will divide all firms into micro, small and medium-sized firms. To mimic the EC definition (see details in footnote 15), we split the sample according to the number of employees and the annual turnover. To be consistent, we include both measures as proxy for firm size in the regressions. Fraser (2009) also uses the numbe of employees and the business assets simultaneously in his model. Besides, to deal with the multicollinearity concerns between these two variables, we run the VIF test, which are smaller than 5, indicating that the correlation problem can be neglected.
} 
but does not seek advice before application.

<Insert Table 4 around here>

Table 4 also provides the difference in means between rejected and approved applicants for all independent variables. The t-statistics suggest that as far as overdrafts are concerned, rejected SMEs were more likely to apply in 2011-2013 and less likely in 2014-2017. Consistent with the trends shown in Table 2 above, results for loans are similar. Further, both in the case of overdrafts and loans, rejected firms tend to be smaller (have fewer employees and lower annual turnovers), younger, sole-traders, less creditworthy and are led by younger owners/leaders. Approved firms have a higher credit balance and tend to be more profitable and internationally traded. Their ownership is usually joint partners (males/females), who are more financially knowledgeable. They generally apply to their main banks, use a credit card, have a business account and apply for relatively higher amounts. In addition, when SMEs apply for overdrafts (not loans), rejected firms tend to be innovative and seek advice before their applications.

\section{Empirical results}

\subsection{Multivariate analysis}

We perform a multivariate analysis to investigate the relationship between bank debt rejections and application date (Model 1 in Table 5). Since the variable rejection is dichotomous, multivariate regressions are estimated using a logistic model. To ensure that the level of multicollinearity is 
acceptable, we compute the VIF test for the independent variables and results are satisfactory (all values are $<5$ ). Table 5 reports the estimated marginal effects for a typical applicant and the Wald test statistics that all coefficients (excluding the constant term) are equal to zero simultaneously. The marginal effect of a significant coefficient is estimated by the discrete changes when other significant coefficients hold the same as a typical applicant.

$<$ Insert Table 5 around here>

Results from Model (1) are reported in the first two columns of Table 5. They suggest that for overdrafts, relative to applications in other years, applications in 2012 are $2.83 \%$ more likely to be rejected. In contrast, applications in 2014-2017 are less likely to be rejected, suggesting looser lending conditions for SMEs in the most recent four years included in our analysis. This latter result is also found for loan applications for which conditions do not appear to change up to 2013 but then show significant negative signs since 2014.

Table 5 also reports the significant marginal effects for Model (2) that include the control variables and results from the application of the Rubin's rule variable selection technique described in Section 4. For both overdrafts and loans, after controlling for several risk characteristics, the changes in lending conditions broadly confirm the findings of Model (1). Relative to applications in 2010 and 2011, those in 2012 and 2013 are $1.57 \%$ and $1.64 \%$ more likely to be rejected for overdrafts. In the following four years, both overdraft and loan markets show more favourable lending conditions relative to years in the wake of financial crisis. 
<Insert Figure 1 around here>

Figure 1 shows that the predicted probability of debt rejection for a typical applicant drops markedly in 2014 and 2015 and then climbs in 2016. As hypothesised in H1, this result might have been influenced by the Brexit referendum which took place in 2016. To test whether the differences before and after Brexit are statistically significant, we run the Wald test with the results reported in the bottom of Table 5. For both overdrafts and loans, the differences between the rejections in 2015, 2016 and 2017 are not statistically significant. Therefore, the lending conditions do not change under the period of great uncertainty in the run-up and in the year following the Brexit referendum. A potential explanation is only a small number of firms will be affected, evidenced by merely $16 \%$ SMEs selfreported Brexit as a major obstacle in a 2016-17 survey (Brown et al., 2019). Another reason might due to the long time spanning and the complicated procedures of Brexit, leading to an insignificant influence in a short-term. A change in lending conditions potentially comes up in the post Brexit, which is out of our sample, although, as pointed out above, data for the last available year used in this study should be interpreted with some caution.

Another important result refers to the variable credit balance $(H 4)$. Most studies omit this variable due to missing values. We apply a survey data multiple imputation technique to deal with this problem and are able to check the effects of credit balance on debt rejections. As far as we are aware there are no other published studies that determine the role of different levels of credit balance in SMEs accounts 
against the probability of rejection. ${ }^{12}$ As hypothesised, our results provide support for our fourth hypothesis (H4) in that a higher credit balance shows a stronger significantly negative marginal effect, suggesting a lower probability of rejection, for both overdrafts and loans.

Regarding owner/manager characteristics, applications from female owned/led SMEs are 2.22\% (3.29\%) more likely to be approved for overdrafts (loans). This finding is in contrast to previous studies' more classical findings that it is much more difficult for female entrepreneurs to access bank lending (e.g. Riding and Swift 1990; Coleman 2000; Bellucci et al. 2010), but conforms to the most recent empirical investigations by Cowling et al. (2016). This result could be interpreted in several ways. On one hand, it could be attributed, and there are a few examples in the literature (e.g. Watson, 2002; Watson and McNaughton, 2007), to a more risk-averse attitude of female managers that will be more likely to select conservative projects or low- risk business plans. On the other hand, it could be that a larger proportion of female-run firms simply did not file a loan application as they anticipated being rejected, as recently evidenced e.g. in Moro et al. (2017). Legal status is also an important factor in reducing rejection rates, a result that contradicts both Armstrong et al. (2013) and Lee and Brown (2017). The lower rejection rate of partnerships can possibly derive from their lower default rate (Cowling and Mitchell, 2003) and from the fact that banks could have more recourse if firms with unlimited liability default thanks to the shared responsibility. Contrary to expectations, we find that for loan applications, SMEs with middle-age owners/leaders (31-50 years old) are 3.97\% more likely

\footnotetext{
12 Studies such as Cole et al. (2004) examine the role of cash holdings in small businesses lending. Although credit balance is close to cash holdings, other studies use cash-to-asset ratio as the proxy for liquidity whereas our variable represents a buffer that banks can use in the event of default.
} 
to be rejected, a result that is at odds with Zhao and Jones-Evans (2017) who focus on the 2011-2014 period and find older (i.e. experienced) owners/leaders have an advantage in loan applications.

Applying to the main bank is found to be $5.82 \%$ less likely to experience overdraft rejections, showing the advantage of a long-term relationship in reducing information asymmetries for overdraft applicants, but not for loan applicants. This is possibly because relative to loans, overdrafts generally have shorter duration and smaller volumes and banks have more monitoring power on overdrafts as they can call back money at any time. The implicaton is that banks will be more cautious when assessing loan applications and tend to focus more on SMEs' ability to pay off the debt.

On firm characteristics, similar determinants on bank debt rejection can be found for overdrafts and loans. Bigger (with either more employees or higher annual turnovers) and older SMEs are less likely to be rejected, revealing an expected negative effect of size and business age, consistent with the findings of Armstrong et al. (2013). The size effect appears to be stronger in loan applications whereas an age effect seems more relevant for overdrafts. Profitable SMEs are 5.21\% (10.73\%) less likely to experience rejections in the case of short-term (long-term) finance whereas innovative SMEs are more likely to be rejected (2.30\% for overdrafts and $4.28 \%$ for loans), as e.g. in Lee et al. (2015). One possible explanation is that innovation 'is essentially a speculative process' (Freel, 2007) and banks are unwilling to bear the accompanying uncertainty. External credit risk rating also plays an important role in determining debt rejection. Relative to SMEs with minimal risk, firms with any higher levels of risk rating are more likely to face rejections. The riskier the SME is, the less likely its application will be approved, in line with the findings of Fraser (2012) and Armstrong et al. (2013). However, for overdraft applications, SMEs with formal written business plans are $1.17 \%$ more likely 
to be rejected, possibly because their proposals are either not sufficiently robust or too ambitious, in which case equity-based finance might be a better choice (Lee and Brown, 2017).

Concerning process- related factors, SMEs using business accounts seem to be associated with considerable better access to overdrafts, maybe because banks can monitor these firms' behavior more closely. Surprisingly and somewhat counterintuitively, seeking advice is found to have a positive effect on overdraft rejection, inconsistent with the findings of Rostamkalaei and Freel (2017) that advice is helpful to improve the bank debt availability. One possible explanation is that SMEs seeking advice before overdraft applications are risky firms which expect to fail or to encounter difficulties during the application process. Therefore, advice seekers are more likely to be rejected (Lee and Drever, 2014). Besides, in the UK SMEs managers are increasingly citing a lack for appropriate advice as well as weak support from banks as a motive not to apply for traditional loans (Close Brothers, 2016). Finally, larger applications tend to be more likely to be approved, possibly relevant to the higher monitoring costs and thus lower profit margins brought by the smaller amounts (Freel et al., 2012).

\subsection{Lending conditions for SMEs with international trades}

Although bank debt rejection rates do not differ across SMEs with and without international trades (coefficients for export and import are insignificant and thus not reported in Table 5), the depreciation of the GBP pound sterling since the Brexit referendum might lead to tight conditions for SMEs with international trades. To test our second hypothesis H2, we re-run regressions for export and import SMEs respectively and report the statistical significant results in Panel A in Table 6. 
<Insert Table 6 around here>

The table shows that both in the case of loans but particularly for overdrafts, import-oriented SMEs benefit from a lower probability of being rejected after 2014. The situation is different for export firms as our empirical results are either not statistically significant (and therefore not reported) or very low. However, we do not find strong evidence that SMEs with international trades suffered tighter credit conditions around Brexit except export firms experienced a 3.62\% lower probability of overdraft rejection in 2015, relative to 2016 and 2017.

Given the changes in the trading outlook in the EU, the uncertainty might exert asymmetric effects for industries with a high vs low share of EU trade. Based on the trade data in 2016 and 2017 (Table A2 in the Appendix), we identify the high EU-traded industries ${ }^{13}$, for example: 'agriculture, hunting and forestry fishing', 'and 'wholesale/retail' for exports and 'construction'; and 'health and social work' for imports. Then we re-run our models for export and import SMEs in their corresponding high EU-traded industries. The significant results are reported in Panel B of Table 6.

For export firms in high EU-traded industries, applications in 2015 are $4.15 \%$ and $10.26 \%$ less likely to be rejected relative to those in 2016 and 2017. Similar evidence is also found for import firms in high EU-traded industries when they apply for loans. Therefore, we do not reject our second

\footnotetext{
${ }^{13}$ Initially we identify industries which trade more with EU than non-EU regions (i.e. the share of EU trade higher than $50 \%$ ) as high EU-traded industries. Unfortunately, estimation issues occur when we run loan rejection regressions for export SMEs in high EU-traded industries, possibly because the sample size is too small to run regressions with so many independent variables. Therefore, we decide to identify industries with above-average share of EU trade as high EU-traded industries.
} 
hypothesis that export and import SMEs operating in industries with a high share of EU trade, experienced tighter lending conditions during and immediately after the Brexit referendum.

\subsection{How much do SMEs size and age matter?}

Our evidence presented above adds to the extant literature by providing additional support that in the UK market, size and age do matter when it comes to applying for traditional bank debt, as smaller and younger SMEs are more likely to be rejected for both overdrafts and loans. Given the costs of not channeling funds to small young firms and start ups for the economy, we carried out an additional test to check the extent to which size and age matter by testing our third hypothesis (H3) using different subsamples.

First, we focus on size and split the full sample into three clusters using the number of employees and the annual turnover. Following the European Commission ${ }^{14}$, we define firms with 0-9 employees and less than $£ 2$ million annual turnovers as 'micro'; firms with 10-49 employees and $£ 2-10$ million annual turnovers as 'small'; and firms with 50-249 employees and £10-25 million annual turnovers as 'medium-sized'. We re-run the regressions in each sub-sample, and report the significant results after variable selection in Table 7.

The table reveals significant results only for micro firms. In all other cases, lending conditions for both overdrafts and loans do not change at all since all coefficients for application date are insignificant.

\footnotetext{
14 For number of employees, limits in EC definition are 10 (between micro and small firms) and 50 (between small and medium-sized firms). Our data can match the limit perfectly. For annual turnovers, limits in EC definition is $€ 2$ million, approx. $£ 1.7$ million (between micro and small firms) and $€ 10$ million, approx. $£ 8$ million (between small and mediumsized firms). The most similar band in our data is $£ 1-1.9$ million and $£ 5-£ 9.9$ million. Therefore, we define micro, small and medium-sized firms in the way described above. Where there are missing values in annual turnover (see Table 4), the definition is made only according to the number of employees.
} 
Relative to 2012 and 2013, micro firms' applications after 2014 are less likely to be rejected for both overdrafts and loans. However, since the coefficients of applications in 2015 and 2016 are not statistically different, the lending conditions around Brexit do not change for micro firms as well .

$<$ Insert Table 7 around here>

Further, we follow Criscuolo et al. (2014) and Ayyagari et al. (2011), and split the sample into start-ups (firms aged less than 2 years), 'young' (firms aged between 2-5 years) and 'mature firms' (more than 5 years). Start-ups are widely recognized as drivers of job creation and also play a crucial role in intensifying competition and driving innovation and opportunities, therefore whether start-ups are credit rationed is a key concern for the economy. Since mature firms account for more than $80 \%$ of the full sample, we further split them into two subsamples: 'firms aged 6-9 years' and 'firms aged more than 10 years'. We re-run the regressions in each sub-sample, with the significant results reported in Table 8.

<Insert Table 8 around here>

Since start-ups' overdraft (loan) applications after 2014 (2013) are 29\% (18\%) less likely to be rejected relative to those in previous year, start-ups appear to benefit from significantly improved conditions, with substantial stronger marginal effects relative to other firms. Looking at the periods before and after Brexit, only firms aged 6-9 years experienced tighter loan conditions while no changes 
are observed for other firms in both overdraft and loan markets. Another noticeable finding is that changes in the loan market are remarkably different for firms aged 6-9 years over the years under investigation, but the differences disappear for more mature firms.

\section{Robustness checks}

In this section, we perform several robustness checks, with the results reported in Table A3 in the Appendix. First, as discussed in Section 4, data for applications in 2010 and 2017 are not complete. To check whether this has any influence on our results, we exclude applications in 2010 and 2017 and then re-run our models. The significant coefficients for application date are shown in Panel A and results are broadly confirmed.

We also test whether our results are robust to different types of rationing. The definition of our dependent variable (see Table 3) includes both types of rationing. To look at them separately, we create another ordinal dependent variable, which equals 0 when the application was approved (not rationed), 1 when it received less credit than it requested (type 1 rationing) and 2 when the applicant was turned down (type 2 rationing). An ordered logit model is employed to perform regressions, with the independent variables staying the same as those listed in Table 3. The results reported in Panel B are very similar, showing the robustness of our results to the definition of bank debt rejection. Besides, the cut-off points between type 1 and type 2 rationing are insignificant for both overdrafts and loans, suggesting no need for separation.

One limitation from the cross sectional nature of our survey data is the simultaneity, i.e. the rejections or approvals of bank debt applications may cause changes in values of independent variables 
within the periods in questions. The majority of our independent variables describe a range, rather than a single value. In this sense, the impact of simultaneity is relatively small. To test this concern empirically, we carry out two additional analysis. First, among the independent variables, we select variables with no simultaneity bias, which will not been influenced by the application outcome. These variables include application date, gender, legal status, owner age, main bank, business age, industry sector, seeking advice and amount applied. The results reported in Panel C are similar, except that the coefficient of applications in 2013 becomes insignificant in overdrafts. Next, given that the surveys were conducted quarterly, we construct a sub-sample using firms which were surveyed in the same quarter as their applications and re-run regressions. As reported in Panel D, the sample size decreases dramatically to 1842 for overdrafts and 887 for loans. However, overall our findings remain robust.

\section{Conclusions}

This paper explores the determinants of bank loan and overdraft rejections for UK SMEs over 2010-17. Various factors have affected banks' ability to lend to opaque and risky small businesses: from the financial crisis and the recession that followed, to the stricter and more onerous bank regulatory framework and the uncertainty around the Brexit referendum result. Recent years have seen renewed efforts from the government and policy-makers both at the national and international level to ensure an adequate flow of credit and increased lending to SMEs. These include for example, national government initiatives, such as in the UK the British Business Bank, as well as measures to encourage banks to lend to small business, like the introduction in 2014 of a short-term corrective measure (known as SME SF or Supporting Factor) to counterbalance the rise in banks' capital requirement 
resulting from the cyclical component of Basel III. Despite these efforts, the SMEs' demand for bank financing is decreasing and this seems a trend that will continue in the future as banks are unable to satisfy their financial needs to survive, grow and invest (European Economy, 2015).

A plethora of theoretical and empirical studies have been conducted that explore credit rationing and analyse the factors determining credit availability; however, limited research is devoted to studying bank lending conditions for SMEs post global financial crisis and during the recession that ensued. As far as we are aware, no study covers a relatively long time period after 2010 and incorporates the years before, during and in the immediate aftermath of the Brexit referendum, which brought further uncertainty and risk to the credit market.

Using the UK SMEs Finance Monitor data over 2010-2017, we examine the changes in bank financing and focus on the determinants of bank debt rejections for a sample of UK SMEs. We use logistic regression models and apply multiple imputations to cope with missing values and the backward stepwise selection approach based on Rubin's Rule to select significant variables in multiply imputed datasets (Wood et al., 2008). In the early 2010s, overdrafts and term loans show slightly different trends although the factors affecting rejections are similar. Our evidence suggests that rejection rates first reduced for both facilities since 2014 and then stayed unchanged in the run-up to the Brexit referendum and its immediate aftermath. Export and import firms operating in industries with a high share of EU trade are found to experience tighter conditions around Brexit. We present fresh evidence that partnerships and firms' female owners and higher initial credit balance are more likely to be approved; while younger, smaller and more innovative SMEs with lower application amount are more likely to be rejected. Finally, start-ups (<2 years) and micro firms (less than 10 
employees and turnover $<£ 2 \mathrm{~m}$ ), appear to experience significantly improved lending conditions after 2014, where the changes are more pronounced compared with other firms.

From a practical perspective, our analysis on the changes in bank lending conditions provides useful insights to the authorities about the current situation in the bank credit market in relation to UK SMEs. Our finding that micro firms may have benefited particularly is a positive development overall but there seems some concern about bigger SMEs that may be in vital need of financing (Cowling et al., 2016). We would also recommend paying a particular attention and considering the case of export and import SMEs as they will need to find less barriers to access to bank finance during the depreciation period of sterling brought by the recent Brexit developments, especially those which have uncertain trading outlook in the EU.

The findings on the determinants of bank debt rejection could also be helpful for UK SMEs as a self-assessment. If SMEs are highly likely to face bank debt rejections, it might be useful considering alternative non-bank financing sources. Indeed, and as mentioned earlier, the market has started recently to compensate to some degree with the growth of various alternative channels to bank credit, from the longer established forms like leasing and hire purchase, to the most modern types of funding via peer-to-peer lending and crowdfunding, as well as challenger banks. Yet, although booming, at present alternative finance's ability to fill the SMEs funding gap is still in its early stages in Europe where 80 per cent of financing to the real economy is directly provided by banks (compared to just 20 per cent in the US). This study has shown that the typical owner is usually lacking financial knowledge and this is likely to be an important part of the problem. Additional government programmes to fill these gaps would be desirable. These could also include targeted programmes for encouraging female 
ownership of small businesses: as our results suggest that SMEs led by women have significantly lower rejection rates compared to their male counterparts. Equally, more structural use of the SME SF recommended by the European Commission to support lending expansion would be desirable. However, there is no evidence to assess whether government programmes have been successful in providing additional stimulus for lending to UK SMEs. As our analysis does not provide a causal evidence between government schemes and bank credit availability for UK SMEs, future research should show the effectiveness of these government programmes. 


\section{References}

ACCA (2011). "Framing the debate: Basel III and SMEs", Accountancy Future.

Allison, P. D. (2012). Missing data. Thousand Oaks, CA: Sage.

Armstrong, A., Davis, E. P., Liadze, I., \& Rienzo, C. (2013). An assessment of bank lending to UK SMEs in the wake of the crisis. National Institute Economic Review, 225(1), R39-R51.

Ayyagari, M., A. Demirguc-Kunt, and V. Maksimovic. (2011) "Small vs. young firms across the world: contribution to employment, job creation, and growth." World Bank Policy Research Working Paper, No. 5631 .

BBB (2016). Small Business finance markets report 2015/16. British Business Bank, February.

BDRC Continental. (2018). Small- and Medium-Sized Enterprise Finance Monitor, 2011-2017. [data collection]. 19th Edition. UK Data Service. SN: 6888, http://doi.org/10.5255/UKDA-SN-6888-20

Bellucci, A., Borisov, A., \& Zazzaro, A. (2010). Does gender matter in bank-firm relationships? Evidence from small business lending. Journal of Banking \& Finance, 34(12), 2968-2984.

Berger, A. N., \& Udell, G. F. (1992). Some evidence on the empirical significance of credit rationing. Journal of Political Economy, 100(5), 1047-1077.

Berger, A. N., \& Udell, G. F. (1995). Relationship lending and lines of credit in small firm finance. Journal of Business, 351-381.

Berger, A. N., \& Udell, G. F. (2002). Small business credit availability and relationship lending: The importance of bank organisational structure. The Economic Journal, 112(477), F32-F53.

Berger, A. N., \& Udell, G. F. (2006). A more complete conceptual framework for SME finance. Journal of Banking \& Finance, 30(11), 2945-2966.

Berger, A. N., Espinosa-Vega, M. A., Frame, W. S., \& Miller, N. H. (2005). Debt maturity, risk, and asymmetric information. The Journal of Finance, 60(6), 2895-2923.

Bodt, E. D., Lobez, F., \& Statnik, J. C. (2005). Credit rationing, customer relationship and the number of banks: an empirical analysis. European Financial Management, 11(2), 195-228.

Boot A.W. (2000), “Relationship banking: What do we know?", Journal of Financial Intermediation, $9(1), 7-25$ 
Brown, R., Liñares-Zegarra, J. M., \& Wilson, J.O. (2019). The (potential) impact of Brexit on UK SMEs: Regional evidence and public policy implications. Regional Studies. 53(5), 761-770.

Buuren, S., \& Groothuis-Oudshoorn, K. (2011). mice: Multivariate imputation by chained equations in R. Journal of Statistical Software, 45(3).

Calabrese, R., Degl'innocenti, M., Zhou, Si (2020). SMEs' access to debt finance in times of uncertainty: Evidence from the Brexit Referendum for providing the data. Journal of Small Business Management, forthcoming.

Cenni, S., Monferrà, S., Salotti, V., Sangiorgi, M., \& Torluccio, G. (2015). Credit rationing and relationship lending. does firm size matter?. Journal of Banking \& Finance, 53, 249-265.

Cole, R. A. (1998). The importance of relationships to the availability of credit. Journal of Banking \& Finance, 22(6), 959-977.

Cole, R. A., \& Dietrich, A. (2013). SME credit availability around the world: Evidence from the World Bank’s Enterprise Surveys. Midwest Finance Association 2013 Annual Meeting Paper. Available at SSRN: https://ssrn.com/abstract=2043624.

Cole, R. A., Goldberg, L. G., \& White, L. J. (2004). Cookie cutter vs. character: The micro structure of small business lending by large and small banks. Journal of Financial and Quantitative Analysis, 39(2), 227-251.

Coleman, S. (2000). Access to capital and terms of credit: A comparison of men-and women-owned small businesses. Journal of Small Business Management, 38(3), 37.

Coleman, S. (2004). The liability of "newness" and small firm access to debt capital: Is there a link?. The Journal of Entrepreneurial Finance, 9(2), 37.

Cooper, A. C., Gimeno-Gascon, F. J., \& Woo, C. Y. (1994). Initial human and financial capital as predictors of new venture performance. Journal of Business Venturing, 9(5), 371-395.

Cowling, M., \& Mitchell, P. (2003). Is the small firms loan guarantee scheme hazardous for banks or helpful to small business?. Small Business Economics, 21(1), 63-71.

Cowling, M., Liu, W., \& Ledger, A. (2012). Small business financing in the UK before and during the current financial crisis. International Small Business Journal, 30(7), 778-800. 
Cowling, M., Liu, W., \& Zhang, N. (2016). Access to bank finance for UK SMEs in the wake of the recent financial crisis. International Journal of Entrepreneurial Behavior \& Research, 22(6), 903-932.

Criscuolo, C., P. N. Gal and C. Menon. (2014). "The Dynamics of employment growth: New evidence from 18 countries", CEP Discussion Paper No.1274, June.

DBEIS (2017). Business population estimates for the UK and regions 2017, Department for Business, Energy \& Industrial Strategy.

DBIS (2015). S Small business survey 2014: SME employers. Department for Business, Innovation \& Skills. BIS Research Paper No. 214, March.

DBIS (2016). SME lending and competition: An international comparison of markets. Department for Business, Innovation \& Skills. BIS Research Paper No. 270, May.

Drakos, K., \& Giannakopoulos, N. (2011). On the determinants of credit rationing: firm-level evidence from transition countries. Journal of International Money and Finance, 30(8), p.1773-1790.

European Economy (2015). Who takes the risks for funding SMEs? Banks, regulation and the real sector, $15(2)$.

Fairlie, R.W. \& Robb, A.M. (2009). Gender differences in business performance: evidence from the characteristics of business owners survey, Small Business Economics, 33(375).

Fasci, M. A., \& Valdez, J. (1998). A performance contrast of male-and female-owned small accounting practices. Journal of Small Business Management, 36(3), 1.

Filippaios, F., \& Stone, Z. (2017). Kent SME Internationalisation Study March 2017.

Fraser, S. (2009). Is there ethnic discrimination in the UK market for small business credit?. International Small Business Journal, 27(5), 583-607.

Fraser, S. (2012). The impact of the financial crisis on bank lending to SMEs: Econometric analysis from the UK survey of SME finances, 2012. Department for Business, Innovation and Skills.

Fraser, S., Bhaumik, S. K., \& Wright, M. (2015). What do we know about entrepreneurial finance and its relationship with growth?. International Small Business Journal, 33(1), 70-88.

Freel, M. S. (2007). Are small innovators credit rationed?. Small Business Economics, 28(1), 23-35.

Freel, M., Carter, S., Tagg, S., \& Mason, C. (2012). The latent demand for bank debt: characterizing “discouraged borrowers”. Small Business Economics, 38(4), 399-418. 
Graham, J. W., Olchowski, A. E., \& Gilreath, T. D. (2007). How many imputations are really needed? Some practical clarifications of multiple imputation theory. Prevention Science, 8(3), 206-213.

Jaffee, D. M., \& Russell, T. (1976). Imperfect information, uncertainty, and credit rationing. Quarterly Journal of Economics, 90(4), 651-666.

Kysucky, V., \& Norden, L. (2015). The benefits of relationship lending in a cross-country context: A metaanalysis. Management Science, 62(1), 90-110.

Lee, N., \& Brown, R. (2017). Innovation, SMEs and the liability of distance: the demand and supply of bank funding in UK peripheral regions. Journal of Economic Geography, 17(1), 233-260.

Lee, N., \& Drever, E. (2014). Do SMEs in deprived areas find it harder to access finance? Evidence from the UK Small Business Survey. Entrepreneurship \& Regional Development, 26(3-4), 337-356.

Lee, N., Sameen, H., \& Cowling, M. (2015). Access to finance for innovative SMEs since the financial crisis. Research Policy, 44(2), 370-380.

Mester, L. J., Nakamura, L. I., \& Renault, M. (2006). Transactions accounts and loan monitoring. The Review of Financial Studies, 20(3), 529-556.

Moro, A., Wisniewski, T. P., \& Mantovani, G. M. (2017). Does a manager's gender matter when accessing credit? Evidence from European data. Journal of Banking \& Finance, 80, 119-134.

Nakamura, L. I. (1991). Commercial bank information: Implications for the structure of banking. Federal Reserve Bank of Philadelphia, No. 92-1.

Petersen, M. A., \& Rajan, R. G. (1994). The benefits of lending relationships: Evidence from small business data. The Journal of Finance, 49(1), 3-37.

Riding, A. L., \& Swift, C. S. (1990). Women business owners and terms of credit: Some empirical findings of the Canadian experience. Journal of Business Venturing, 5(5), 327-340.

Ritter, G. (2014). Robust Cluster Analysis and Variable Selection. CRC Press.

Rostamkalaei, A., \& Freel, M. (2017). Business advice and lending in small firms. Environment and Planning C: Politics and Space, 35(3), 537-555.

Schafer, J. L. (1999). Multiple imputation: a primer. Statistical Methods in Medical Research, 8(1), 3-15. Stiglitz, J. E., \& Weiss, A. (1981). Credit rationing in markets with imperfect information. The American Economic Review, 71(3), 393-410. 
Udell, G. F. (2015). SME Access to intermediated credit: What do we know and what don't we know? In Reserve Bank of Australia, Proceedings of Small Business Conditions and Finance Conference, 61109.

Van de Ven, W. P., \& Van Praag, B. M. (1981). The demand for deductibles in private health insurance: A probit model with sample selection. Journal of Econometrics, 17(2), 229-252.

Watson, J. (2002). Comparing the performance of male-and female-controlled businesses: relating outputs to inputs. Entrepreneurship: Theory and Practice, 26(3), 91-101.

Watson, J., \& McNaughton, M. (2007). Gender differences in risk aversion and expected retirement benefits. Financial Analysts Journal, 63(4), 52-62.

White, I. R., Royston, P., \& Wood, A. M. (2011). Multiple imputation using chained equations: issues and guidance for practice. Statistics in Medicine, 30(4), 377-399.

Wood, A. M., White, I. R., \& Royston, P. (2008). How should variable selection be performed with multiply imputed data?. Statistics in Medicine, 27(17), 3227-3246.

Zhao, T., \& Jones-Evans, D. (2017). SMEs, banks and the spatial differentiation of access to finance. Journal of Economic Geography, 17(4), 791-82. 